\title{
First report of biomimetic synthesis of silver nanoparticles using aqueous callus extract of Centella asiatica and their antimicrobial activity
}

\author{
Vasudeva Reddy Netala • Venkata Subbaiah Kotakadi • \\ Venkateswarlu Nagam · Pushpalatha Bobbu • \\ Sukhendu Bikash Ghosh · Vijaya Tartte
}

Received: 4 September 2014 / Accepted: 20 October 2014/Published online: 2 November 2014

(C) The Author(s) 2014. This article is published with open access at Springerlink.com

\begin{abstract}
The present study reports the simple and ecofriendly approach for biosynthesis of silver nanoparticles (AgNPs) using aqueous callus extract as reducing agent for the first time. The formation of AgNPs was initially confirmed by characteristic surface plasmon resonance (SPR) peak $453 \mathrm{~nm}$ by UV-Visible spectroscopy. FTIR spectrum shows different functional groups which probably involved in the synthesis and stabilization of AgNPs. TEM analysis determined the well-dispersed AgNPs with roughly spherical shape and size ranging 5-40 nm. XRD patterns revealed the crystalline nature of AgNPs with face-centered cubic (fcc) lattice. The synthesized AgNPs were found to have strong inhibitory activity against Staphylococcus aureus, Bacillus subtilis, Escherichia coli, Pseudomonas aeruginosa.
\end{abstract}

Keywords Biomimetic - Nanoparticles - FTIR - TEM · XRD $\cdot$ Antimicrobial activity

V. R. Netala $\cdot$ P. Bobbu

Department of Biotechnology, Sri Venkateswara University, Tirupati 517 502, AP, India

V. S. Kotakadi $(\square)$

DST-PURSE Centre, Sri Venkateswara University,

Tirupati 517 502, AP, India

e-mail: kotakadi72@gmail.com

V. Nagam $\cdot$ V. Tartte $(\bowtie)$

Department of Botany, Sri Venkateswara University,

Tirupati 517 502, AP, India

e-mail: tvijayasvu@yahoo.com

S. B. Ghosh

Board of Research in Nuclear Sciences, NABTD, BARC,

Mumbai 400085, MH, India

\section{Introduction}

Nanoparticles research is an area of great scientific interest due to their large surface area to volume ratio and diverse physicochemical characteristics. Preparation of silver nanoparticles (AgNPs) has attracted particularly considerable attention due to wide variety of applications including electrical batteries (Wang et al. 2010), optical receptors (Karimzadeh and Mansour 2010), sensors (Dubas and Pimpan 2008), catalysts in chemical reactions (Edison and Sethuraman 2012), bioactive materials (Blaker et al. 2004) and antimicrobial agents (Saxena et al. 2012). AgNPs are most promising as they are possessing antimicrobial properties due to larger surface area to volume ratio which is of great interest to researchers due to the increasing microbial resistance against antibiotics, metal ions and development of resistant strains. It is very well known that silver ions and silver-based compounds are lethal to microorganisms and no organism has ever been reported to develop resistance against silver. This aspect of silver makes it an excellent antimicrobial agent and thus was used in skin ointments and creams to improve wound healing (Zhao and Stevens 1998; Elliott 2010).

Various physical and chemical methods which include gamma irradiation assisted (Huang et al. 2009), ultrasound irradiation assisted (Abbasi et al. 2012), thermal decomposition (Yang et al. 2007), laser ablation (Simakin et al. 2004), electrochemical assisted (Hosseini and Momeni 2010), sonochemical synthesis (Salkar et al. 1999) and chemical reduction (Lee and Meisel 1982) methods were employed to synthesize AgNPs, but most of these methods are expensive and involve the use of toxic chemicals which may pose potential environmental and biological risks. Hence, there is a need to develop eco-friendly procedures. Biosynthesis of AgNPs using microorganisms, enzymes, 
and plants or plant extracts have been suggested as cost effective, eco-friendly alternatives to chemical and physical methods. Various plant extracts which include Andrographis paniculata (Kotakadi et al. 2014), Catharanthus roseus (Kotakadi et al. 2013), Cassia alata (Gaddam et al. 2014), Cissus quadrangularis (Valli and Vaseeharan 2012), Coleus aromaticus (Vanaja and Annadurai 2012), Tithonia diversifolia (Tran et al. 2013) and Brucea javanica (Salprima et al. 2013) were reported for the biosynthesis of AgNPs.

Centella asiatica, an important medicinal plant belongs to the Umbelliferae family. It is a valued ethnomedicine in traditional Indian ayurvedic system. It is used for improving memory, treat gastric ulcers and kidney troubles (Kumar and Gupta 2002). The bioactive compounds of this plant also possess antitumor (Babu et al. 1995), immunomodulating (Wang 2003), cardioprotective (Pragada et al. 2004) and anti-depressant activities (Chen et al. 2005). Development of callus culture methods from the leaf explants will be alternative approaches for the optimization of bioactive compounds. The callus cultures of $C$. asiatica are explored for the biosynthesis of AgNPs as another important pharmaceutical or biomedical application of $C$. asiatica.

In this study, we first report the synthesis of AgNPs using aqueous callus extract of $C$. asiatica. The synthesized AgNPs were characterized by UV-Vis spectroscopy, Fourier transform infrared spectroscopy (FTIR), Transmission electron microscopy (TEM) and X-ray diffraction method (XRD). The antimicrobial activity of the AgNPs was evaluated against $S$. aureus, B. subtilis, E. coli and $P$. aeruginosa to check their biomedical importance.

\section{Materials and methods}

Plant material collection

Centella asiatica plants were collected from medicinal plants garden and authenticated with taxonomist, Department of Botany, Sri Venkateswara University, Tirupati, Andhra Pradesh, India. The voucher specimen was deposited in the herbarium (VM-0912).

\section{Explant sterilization}

The young leaves of $C$. asiatica were excised and washed thoroughly with sterile double distilled water for 3-5 min to remove the dust. Then leaves were treated with $10 \%$ $\mathrm{NaOCl}$ for 60-90 s. Surface sterilization was done under aseptic conditions using $0.1 \% \mathrm{HgCl}_{2}$ for $30-45 \mathrm{~s}$ followed by a final rinse 2-3 times with sterile double distilled water.
Callus induction and culture conditions

The sterilized leaves were blotted on sterile blotting paper, cut into small parts $(0.8 \times 1.0 \mathrm{~cm})$ and inoculated on Murashige-Skoog (MS) medium containing $2.0 \mathrm{mg} / \mathrm{L}$ of $\alpha$ naphthalene acetic acid and $1.0 \mathrm{mg} / \mathrm{L}$ of kinetin as callus inducing plant growth regulators (Murashige and Skoog 1962). The cultures were incubated at $23{ }^{\circ} \mathrm{C}$ under photoperiod of $12-\mathrm{h}$ light with intensity $45-50 \mu \mathrm{mol} / \mathrm{m}^{2} / \mathrm{s}$.

Preparation of aqueous callus extracts

Fresh biomass of callus was collected and dried in the oven at $40{ }^{\circ} \mathrm{C}$ for $24 \mathrm{~h}$. The dried biomass of callus was crushed into fine powder. Five gram of fine powder was taken in $250 \mathrm{ml}$ Erlenmeyer flask, added $50 \mathrm{ml}$ of sterile double distilled water and boiled for $10-15 \mathrm{~min}$ at $70{ }^{\circ} \mathrm{C}$. The extract was then allowed to cool to room temperature and then filtered using Whatman No. 1 filter paper. The filtrate named aqueous callus extract was used for biosynthesis of AgNPs. The extract was also stored at $4{ }^{\circ} \mathrm{C}$ for future use.

\section{Biosynthesis of AgNPs}

Silver nitrate $\left(\mathrm{AgNO}_{3}\right)$ was purchased from Himedia, Bangalore, India. The reaction mixture was prepared by adding $10 \mathrm{ml}$ of the callus extract to $90 \mathrm{ml}$ aqueous solution of $1 \mathrm{mM} \mathrm{AgNO}_{3}$ (9:1 ratio-optimized concentration) in $250 \mathrm{ml}$ Erlenmeyer flask and incubated in a dark place at $35{ }^{\circ} \mathrm{C}$ for about $48 \mathrm{~h}$. The primary detection of reduction of silver ions $\left(\mathrm{Ag}^{+}\right)$to $\mathrm{AgNPs}\left(\mathrm{Ag}^{\circ}\right)$ was carried out by observing the color change of the reaction mixture from light yellow to dark brown. Confirmation of the synthesis and characterization was carried out by spectrophotometric measurements.

\section{Characterization of AgNPs}

The characteristic SPR peak of the AgNPs solution was recorded using UV-Visible spectroscopy (Analytical Technologies Ltd, India). The FTIR spectrum was obtained in the range of $500-4000 \mathrm{~cm}^{-1}$ with the resolution of $2 \mathrm{~cm}^{-1}$ by employing alpha interferometer FTIR. TEM micrographs to determine the size and shape of the synthesized AgNPs were obtained using FEI Tecnai F12 (Philips, Holland) operated at $100 \mathrm{kV}$. XRD patterns to confirm the crystalline nature of AgNPs were recorded using $\mathrm{Cu} \mathrm{K} \alpha$ radiation source on an Ultima IV X-ray powder diffractometer (Rigaku, Tokyo, Japan). 


\section{Antimicrobial activity}

The antimicrobial activity of the AgNPs was evaluated against pathogenic bacteria S. aureus, B. subtilis (Grampositive) and E.coli, P. aeruginosa (Gram-negative). The antimicrobial activity was carried out with $24 \mathrm{~h}$ active cultures by employing disc diffusion method (Ghassan et al. 2013; Cruickshank 1968). Two hundred microlitre of bacterial inoculum was swabbed on the surface of nutrient agar medium plates. Sterile discs impregnated with $20 \mu \mathrm{l}$ of AgNPs solution at a concentration of $100 \mu \mathrm{g} / \mathrm{ml}$ were then placed on the surface of the inoculated medium. Sterile disc without any treatment was used as negative control. Standard antibiotic was used as positive control. The agar plates were incubated at $37{ }^{\circ} \mathrm{C}$ for $24 \mathrm{~h}$. The values of diameter of zone of inhibition (ZOI) were represented.

\section{Results and discussion}

Callus was initiated after 14 days of inoculation on MS medium. Light yellow and friable callus (Fig. 1) was harvested after 6th week of inoculation. The callus at this stage considered well developed and matured due to secretion of plant secondary metabolites and proteins and hence is used for the synthesis of AgNPs.

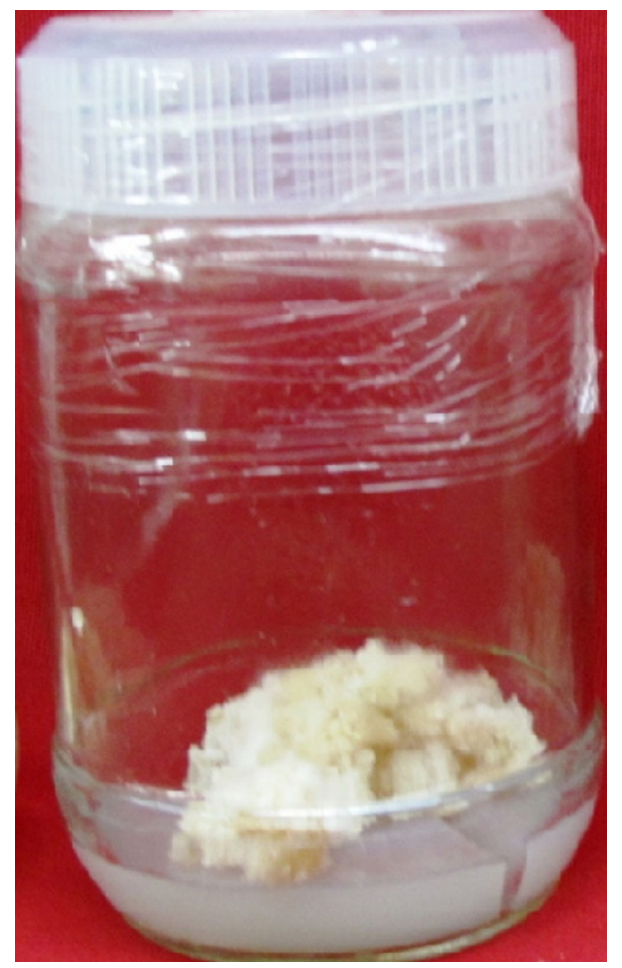

Fig. 1 Light yellow and friable callus developed from the leaves of Centella asiatica on MS media supplemented with $2.0 \mathrm{mg} / \mathrm{L}$ of $\alpha$ naphthalene acetic acid and $1.0 \mathrm{mg} / \mathrm{L}$ of kinetin
The synthesis of AgNPs was initially observed by the color change from light yellow to dark brown color (Fig. 2). The color change is due to the excitation of surface plasmon resonance vibrations in AgNPs. Noble metal nanoparticles with bright and fascinating colors owing to their localized surface plasmon resonance effect offer convenient surface bioconjugation using molecular biomarkers which in turn offer wide variety of applications (Noginov et al. 2007; Stamplecoskie and Scaiano 2010).

$\mathrm{UV}-\mathrm{Vis}$ analysis

The UV-Vis absorption spectra of the AgNPs showed (Fig. 3) the absorbance peak at $453 \mathrm{~nm}$, confirmed the synthesis of AgNPs. Owing to the surface plasmon vibrations excited, AgNPs exhibited strong absorption peak in the visible range named surface plasmon resonance (SPR) peak. The SPR peak and different molecules of callus extracts could be responsible for capping and stabilization of AgNPs formed. This characteristic SPR peak may also correspond for the spherical shape of AgNPs (Kotakadi et al. 2014; Noginov et al. 2007; Stamplecoskie and Scaiano 2010).

\section{FTIR analysis}

The FTIR spectrum (Fig. 4) showed peaks at 3273, 2922 , $2361,1603,1515,1369,1025 \mathrm{~cm}^{-1}$. The peak at $3273 \mathrm{~cm}^{-1}$ could be assigned to $\mathrm{N}-\mathrm{H}$ stretching vibrations of the secondary amide of the protein and the peak at $2922 \mathrm{~cm}^{-1}$ could be assigned to $\mathrm{C}-\mathrm{H}$ stretching of methylene groups of the protein and $2361 \mathrm{~cm}^{-1}$ corresponding to $\mathrm{N}-\mathrm{H}$ stretching/C-O stretching vibrations (Bozanic et al. 2010; Kumar and Mamidyala 2011; Mahitha 2011). The peak at $1603 \mathrm{~cm}^{-1}$ corresponds to asymmetric $\mathrm{C}=\mathrm{O}$ stretching vibration and/or aromatic $\mathrm{C}=\mathrm{C}$ stretching vibration (Aruna et al. 2012; Valentina and Boris 2013; Bellamy 1975). The peak at $1515 \mathrm{~cm}^{-1}$ corresponds to amide II linkage of the proteins (Monali 2009). The peak at 1369 and $1025 \mathrm{~cm}^{-1}$ could be assigned to $\mathrm{C}-\mathrm{O}$ stretching and $\mathrm{O}-\mathrm{H}$ deformation of phenolic OH groups (Valentina and Boris 2013; Bellamy 1975; Monali 2009). FTIR peaks and assigned functional groups clearly indicated in the Table 1 . Based on the FTIR studies, it is reported that phenolic compounds present in the callus extract could be responsible for the reduction of silver ions $\left(\mathrm{Ag}^{+}\right)$into $\operatorname{AgNPs}\left(\mathrm{Ag}^{\circ}\right)$. Proteins could be responsible for both synthesis and stabilization of AgNPs. But the exhaustive mechanism of the synthesis of nanoparticles in this bio-based reduction by callus extract is to be further elucidated. 
Fig. 2 Yellow color of the Centella asiatica callus extract exposed to $\mathrm{AgNO}_{3}$ (a) and dark brown color of the reaction mixture after $48 \mathrm{~h}$ of incubation

(b)

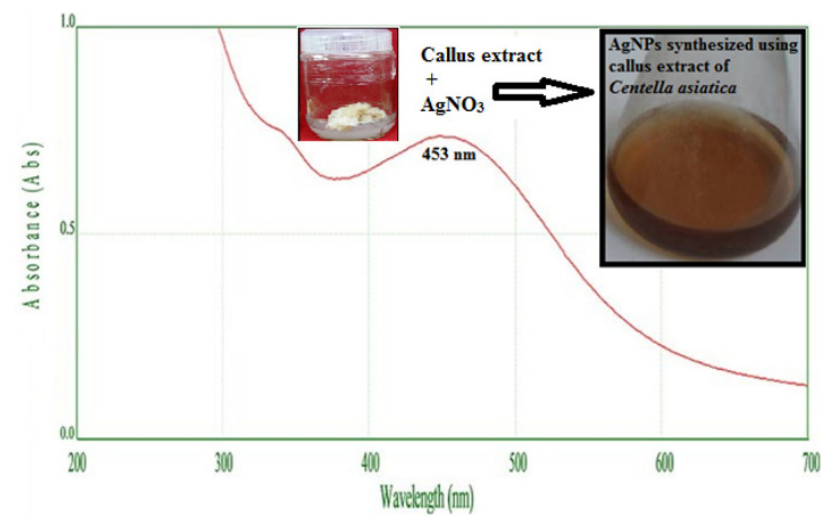

Fig. 3 Characteristic SPR peak of AgNPs shown by UV-Vis absorption spectroscopy
(A)

Callus extract

(B)

\section{)}

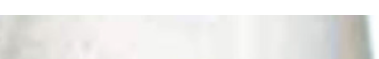

\section{AgNPs}

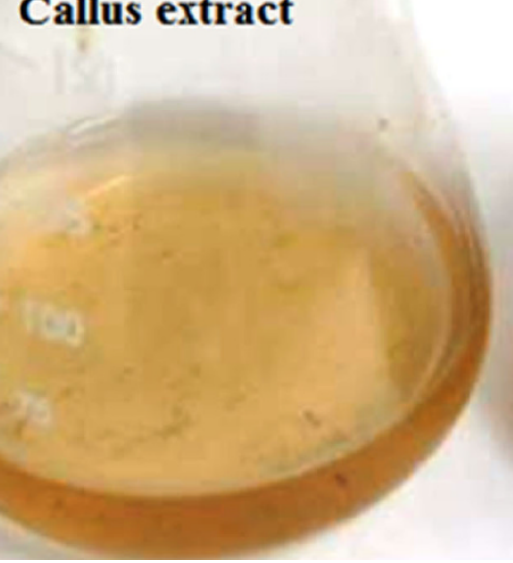

TEM analysis

From the TEM micrograph (Fig. 5) it is clear that the synthesized AgNPs were well dispersed and their shape is roughly spherical with the size ranging 5-40 nm. A small percentage of AgNPs in solution was partially aggregated but uniform in their size and shape. The TEM results are consistent with many earlier reports (Tran et al. 2013; Salprima 2013).

\section{XRD analysis}

A representative XRD pattern (Fig. 6) of the synthesized AgNPs showed four distinct diffraction peaks at $38.26^{\circ}$,

Fig. 4 FTIR spectra of AgNPs produced by callus extract of Centella asiatica

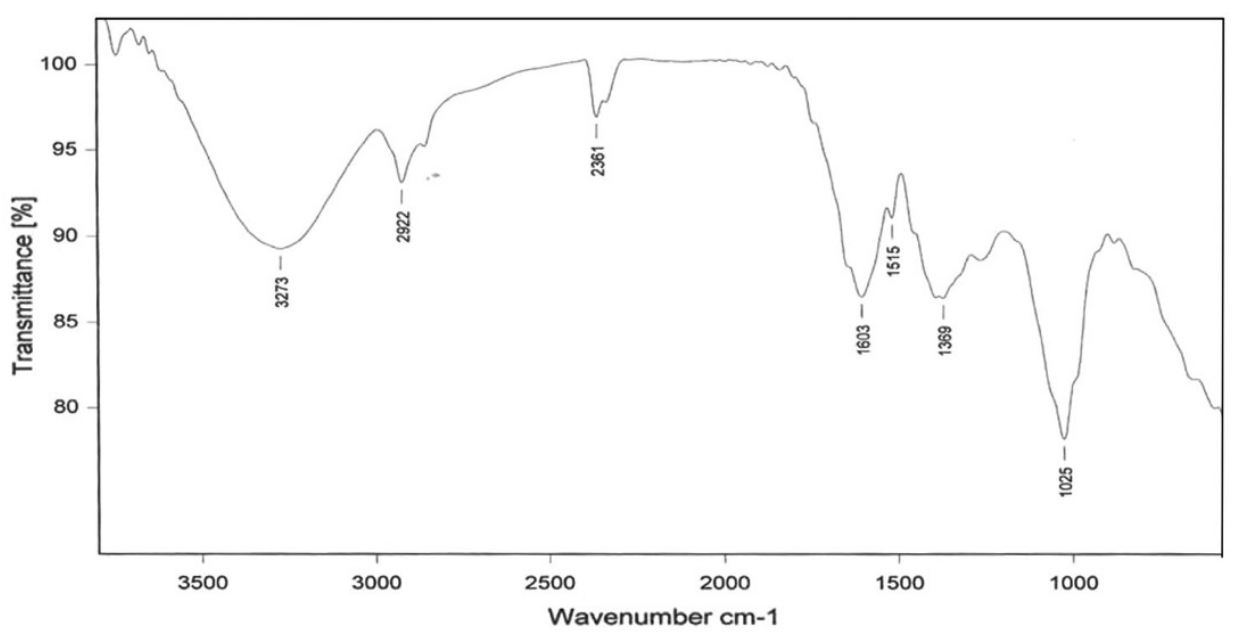


Table 1 FTIR peaks and corresponding functional groups

\begin{tabular}{|c|c|c|c|}
\hline $\begin{array}{l}\text { S. } \\
\text { No. }\end{array}$ & $\begin{array}{l}\text { FTIR } \\
\text { peak } \\
\left(\mathrm{cm}^{-1}\right)\end{array}$ & $\begin{array}{l}\text { Functional group } \\
\text { assigned }\end{array}$ & References \\
\hline 1 & 3273 & $\begin{array}{l}\mathrm{N}-\mathrm{H} \text { stretching of } \\
\text { amide II }\end{array}$ & $\begin{array}{l}\text { Gaddam et al. (2014), Valli and } \\
\text { Vaseeharan (2012) and Vanaja } \\
\text { and Annadurai (2012) }\end{array}$ \\
\hline 2 & 2922 & $\begin{array}{l}-\mathrm{C}-\mathrm{H} \text { stretching } \\
\text { of }-\mathrm{CH}_{2} \text { of } \\
\text { protein }\end{array}$ & $\begin{array}{l}\text { Gaddam et al. (2014), Valli and } \\
\text { Vaseeharan (2012) and Vanaja } \\
\text { and Annadurai (2012) }\end{array}$ \\
\hline 3 & 2361 & $\begin{array}{l}\mathrm{N}-\mathrm{H} / \mathrm{C}-\mathrm{O} \\
\text { stretching }\end{array}$ & Tran et al. (2013) \\
\hline 4 & 1603 & $\begin{array}{l}\mathrm{C}-\mathrm{O} / \text { aromatic } \\
\mathrm{C}-\mathrm{C} \text { stretching }\end{array}$ & $\begin{array}{l}\text { Salprima et al. (2013), Kumar and } \\
\text { Gupta (2002) and Babu et al. } \\
\text { (1995) }\end{array}$ \\
\hline 5 & 1515 & Amide II linkage & Wang et al. (2003) \\
\hline 6 & 1369 & $\begin{array}{l}\mathrm{C}-\mathrm{O} \text { stretching/ } \\
\mathrm{O}-\mathrm{H} \\
\text { deformation }\end{array}$ & $\begin{array}{l}\text { Kumar and Gupta (2002) and } \\
\text { Babu et al. (1995) }\end{array}$ \\
\hline 7 & 1025 & $\begin{array}{l}\mathrm{C}-\mathrm{O} \text { stretching/ } \\
\mathrm{O}-\mathrm{H} \\
\text { deformation }\end{array}$ & $\begin{array}{l}\text { Kumar and Gupta (2002) and } \\
\text { Babu et al. (1995) }\end{array}$ \\
\hline
\end{tabular}

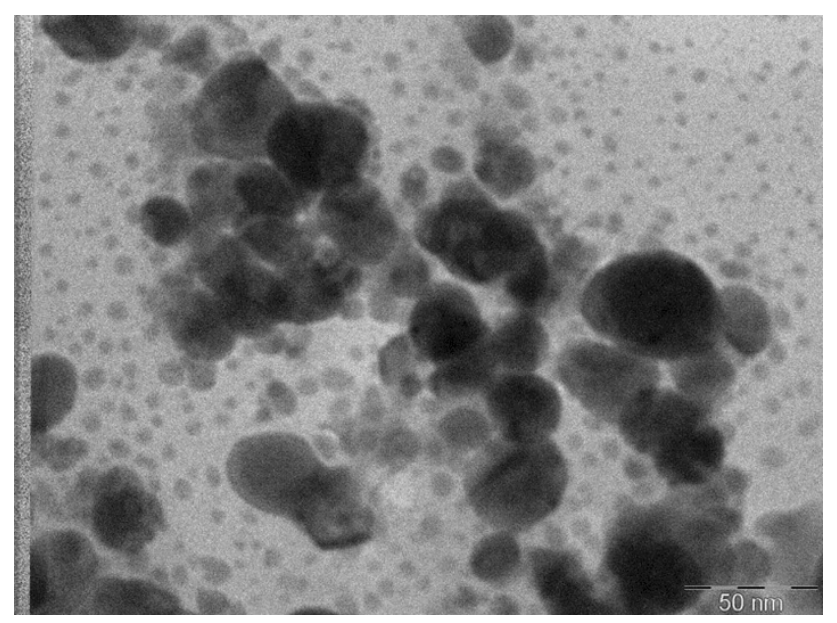

Fig. 5 TEM micrograph of silver nanoparticles by callus extract of Centella asiatica (inset bar $50 \mathrm{~nm}$ )

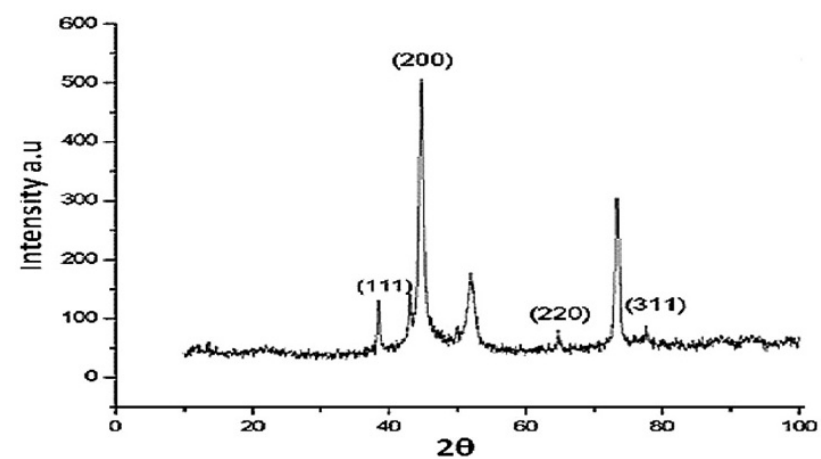

Fig. 6 XRD pattern obtained for AgNPs produced by callus extract of Centella asiatica $44.58^{\circ}, 64.51^{\circ}$ and $77.62^{\circ}$ corresponding to $\left(\begin{array}{lll}1 & 1 & 1\end{array}\right),\left(\begin{array}{lll}2 & 0 & 0\end{array}\right)$, ( $\left.\begin{array}{lll}2 & 2 & 0\end{array}\right)$ and ( $\left.\begin{array}{lll}3 & 1 & 1\end{array}\right)$ planes of the face-centered cubic (fcc) lattice of silver, respectively (JCPDS File No 87-0720), and revealed the crystalline nature of AgNPs. The XRD results are consistent with those reported for face-centered cubic (fcc) lattice of silver (Gaddam et al. 2014; Aruna et al. 2012).

Antimicrobial activity

After incubation for $24 \mathrm{~h}$, growth inhibition (ZOI) was observed around discs impregnated with silver nanoparticles and positive control (streptomycin), but the negative control discs could not produce ZOI (Fig. 7). AgNPs exhibited strong antimicrobial activity against both Grampositive, S. aureus, B. subtilis and Gram-negative bacteria, E. coli, $P$. aeruginosa and formed the ZOI of diameters 21.3, 19.4, 16.2 and $18.8 \mathrm{~mm}$, respectively (Table 2). AgNPs showed strong inhibition against Gram-positive bacteria compared to Gram-negative bacteria. Higher ZOI was noticed for $S$. aureus compared with other Grampositive strain. The results obtained for antimicrobial activity are very effective and consisted with many earlier reports of plant extract assisted synthesis of AgNPs (Kotakadi 2013; Mahitha 2011; Aruna et al. 2012). Many researchers reported the possible mechanism of action behind the inhibitory activity of AgNPs against different bacterial strains. AgNPs could preferentially bind the cell membrane and cause dissipation of proton motive force (PMF) and thus membrane destruction occurs. AgNPs increase the membrane permeability by forming pores or pits on the membranes and finally results in cell death (Morones et al. 2005; Lok et al. 2006; Shahverdi 2007). AgNPs bind with bacterial cell membrane and enter into cytosol of bacteria by dissipating PMF and interrupts bacterial DNA replication system and inactivates synthesis of proteins causing the inhibition of bacterial growth (Kotakadi 2013).

\section{Conclusion}

In the present study, we have synthesized AgNPs of 5-40 $\mathrm{nm}$ in size with spherical shape using aqueous callus extract of Centella asiatica for first time. AgNPs synthesized by aqueous callus extract were very distinct with very small size, well-defined shape, well dispersed, crystalline nature and clearly proved their biomedical importance by exhibiting strong antimicrobial activity against both Grampositive and Gram-negative bacteria. Thus AgNPs possess important applications in biomedical or pharmaceutical industry for the preparation of antibacterial skin ointments. 


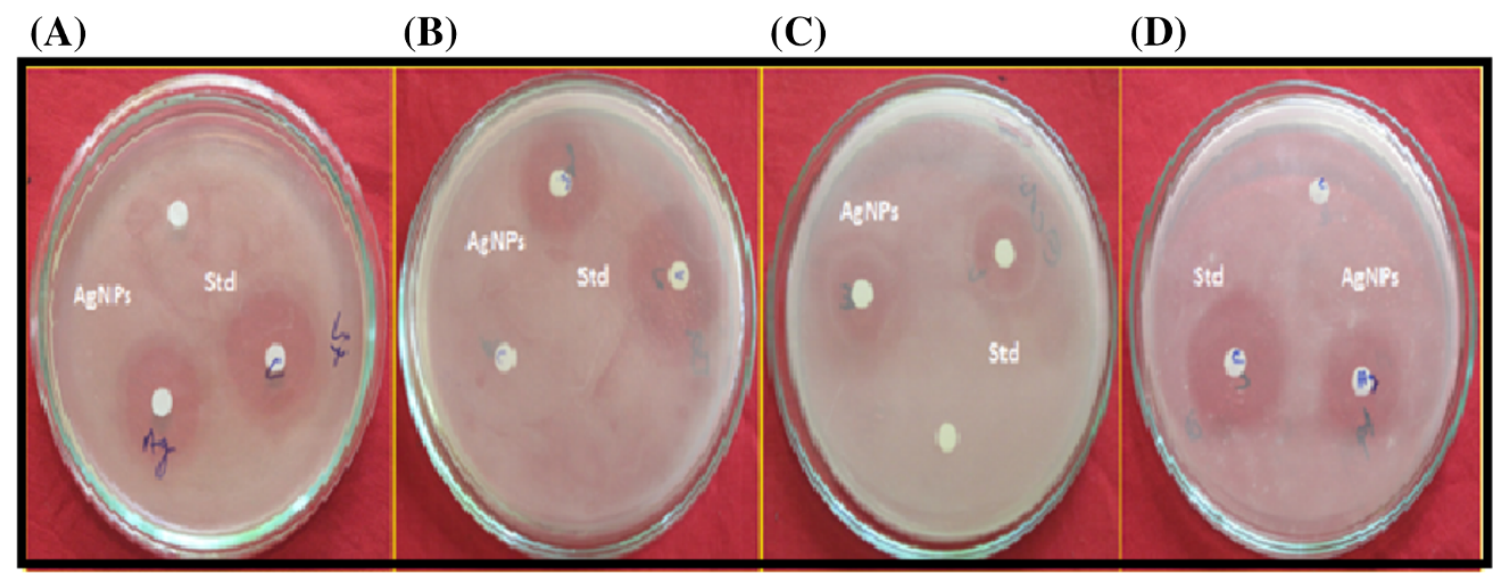

Fig. 7 Antimicrobial activity of silver nanoparticles against S. aureus (a), B. subtilis (b), E. coli (c) and P. aeruginosa (d)

Table 2 Antimicrobial activity of AgNPs produced by callus extract of Centella asiatica against pathogenic bacteria

\begin{tabular}{llll}
\hline $\begin{array}{l}\text { S. } \\
\text { No. }\end{array}$ & $\begin{array}{l}\text { Tested } \\
\text { organism }\end{array}$ & $\begin{array}{l}\text { Zone of inhibition } \\
(\mathrm{mm}) \text { of AgNPs }\end{array}$ & $\begin{array}{l}\text { Zone of inhibition } \\
(\mathrm{mm}) \text { of standard drug }\end{array}$ \\
\hline A & $\begin{array}{c}\text { Staphylococcus } \\
\text { aureus }\end{array}$ & 21.3 & 23.4 \\
B & $\begin{array}{c}\text { Bacillus subtilis } \\
\text { C }\end{array}$ & 19.4 & \\
Escherichia coli & 16.2 & 21.8 \\
D & $\begin{array}{c}\text { Pseudomonas } \\
\text { aeruginosa }\end{array}$ & 18.8 & 16.8 \\
& & 21.2 \\
\hline
\end{tabular}

Acknowledgments The authors are grateful to DAE-BRNS, BARC, Mumbai, MH, India., for providing financial assistance. The authors are also thankful to CSIR, IICT-Hyderabad, AP, India., for technical assistance.

Conflict of interest The authors declare that there is no conflict of interest.

Open Access This article is distributed under the terms of the Creative Commons Attribution License which permits any use, distribution, and reproduction in any medium, provided the original author(s) and the source are credited.

\section{References}

Abbasi AR, Kalantary H, Yousefi M, Ramazani A, Morsali A (2012) Synthesis and characterization of Ag nanoparticles @polyethylene fibers under ultrasound irradiation. Ultrason Sonochem 19:853-857

Aruna JK, Sashidhar RB, Arunachalam J (2012) Aqueous extract of gum olibanum (Boswellia serrata): a reductant and stabilizer for the biosynthesis of antibacterial silver nanoparticles. Process Biochem 47:1516-1520

Babu TD, Kuttan G, Padikkala J (1995) Cytotoxic and anti-tumour properties of certain taxa of Umbelliferae with special reference to Centella asiatica (L.) Urban. J Ethnopharmacol 48:53-57

Bellamy LJ (1975) The infrared spectra of complex molecules. Chapman \& Hall, London
Blaker JJ, Nazhat SN, Boccaccini AR (2004) Development and characterization of silver-doped bioactive glass-coated sutures for tissue engineering and wound healing applications. Biomaterials 25:1319-1329

Bozanic DK, Trandafilovic LV, Luyt AS, Djokovic V (2010) 'Green' synthesis and optical properties of silver-chitosan complexes and nanocomposites. React Funct Polym 70:869-873

Chen Y, Han T, Rui Y, Yin M, Qin L, Zheng H (2005) Effects of total triterpenes of Centella asiatica on the corticosterone levels in serum and contents of monoamine in depression rat brain. Zhong Yao Cai 28:492-496

Cruickshank R (1968) Medical microbiology: a guide to diagnosis and control of infection. E\&S Livingston Ltd., Edinburgh

Dubas ST, Pimpan V (2008) Green synthesis of silver nanoparticles for ammonia sensing. Talanta 76(1):29-33

Edison T, Sethuraman M (2012) Instant green synthesis of silver nanoparticles using Terminalia chebula fruit extract and evaluation of their catalytic activity on reduction of Methylene blue. Process Biochem 47:1351-1357

Elliott C (2010) The effects of silver dressings on chronic and burns wound healing. Br J Nurs 19:S32-S36

Gaddam SA, Kotakadi VS, Gopal DVRS, Rao YS, Reddy AV (2014) Efficent and robust biofabrication of silver nanoparticles by Cassia alata leaf extract and their antimicrobial activity. J Nanostruct Chem 4(82):1-9

Ghassan MS, Wasnaa HM, Thorria RM, Ahmed AAA, Abdul AHK, Abu BM (2013) Green synthesis, antimicrobial and cytotoxic effects of silver nanoparticles using Eucalyptus chapmaniana leaves extract. Asian Pac J Trop Biomed 3(1):58-63

Hosseini M, Momeni MM (2010) Silver nanoparticles dispersed in polyaniline matrixes coated on titanium substrate as a novel electrode for electro-oxidation of hydrazine. J Mater Sci 45:3304-3310

Huang NM, Radiman S, Lim HN, Khiew PS, Chiu WS, Lee KH, Syahida A, Hashim R, Chia CH (2009) Gamma-ray assisted synthesis of silver nanoparticles in chitosan solution and antibacterial properties. Chem Eng J 155:499-507

Karimzadeh R, Mansour N (2010) The effect of concentration on the thermo-optical properties of colloidal silver nanoparticles. Opt Laser Technol 42(5):783-789

Kotakadi VS, Rao YS, Gaddam SA, Prasad TNVKV, Reddy AV, Gopal DVRS (2013) Simple and rapid biosynthesis of stable silver nanoparticles using dried leaves of Catharanthus roseus. Linn. G. Donn and its anti microbial activity. Colloids Surf B Biointerfaces 105:194-198 
Kotakadi VS, Gaddam SA, Rao YS, Prasad TNVKV, Reddy AV, Gopal DVRS (2014) Biofabrication of silver nanoparticles by Andrographis paniculata. Eur J Chem 73:135-140

Kumar MHV, Gupta YK (2002) Effect of different extracts of Centella asiatica on cognition and markers of oxidative stress in rats. J Ethnopharmacol 79:253-260

Kumar CG, Mamidyala SK (2011) Extracellular synthesis of silver nanoparticles using culture supernatant of Pseudomonas aeruginosa. Colloids Surf B 84:462-466

Lee PC, Meisel D (1982) Adsorption and surface-enhanced Raman of dyes on silver and gold sols. J Phys Chem 86:3391-3395

Lok CN, Ho CM, Chen R, He QY, Yu WY, Sun H, Tam PK, Chiu JF, Che CM (2006) Proteomic analysis of the mode of antibacterial action of silver nanoparticles. J Proteome Res 5:916-924

Mahitha B, Prasad Raju BD, Dillip GR, Reddy CM, Mallikarjuna K, Manoj L (2011) Biosynthesis characterization and antimicrobial studies of AgNPs extract from Bacopa Monniera whole plant. Dig J Nanomater Biostruct 6:135-142

Monali G, Jayendra K, Avinash I, Aniket G, Mahendra R (2009) Fungus-mediated synthesis of silver nanoparticles and their activity against pathogenic fungi in combination with fluconoazole. Nanomed Nanotech Biol Med 5:382-386

Morones JR, Elechiguerra JL, Camacho A, Holt K, Kouri JB, Ramirez JT, Yacama JM (2005) The bactericidal effect of silver nanoparticles. Nanotechnology 16:2346-2353

Murashige T, Skoog F (1962) A revised medium for rapid growth and bioassays with tobacco tissue cultures. Physiol Plant 15:473-497

Noginov M, Zhu G, Bahoura M, Adegoke J, Small C, Ritzo BA, Drachav VP, Shalaev VM (2007) The effect of gain and absorption on surface plasmons in metal nanoparticles. Appl Phys B 86(3):455-460

Pragada RR, Veeravalli KK, Chowdary KP, Routhn KP (2004) Cardioprotective activity of Hydrocotyle asiatica $L$. in ischemiareperfusion induced myocardial infraction in rats. J Ethnopharmacol 93:105-108

Salkar RA, Jeevanandam P, Aruna ST, Koltypin Y, Gedanken A (1999) The sonochemical preparation of amorphous silver nanoparticles. J Mater Chem 9:1333-1335

Salprima YS, Notriawan D, Angasa E, Suharto TE, Hendri J, Nishina Y (2013) Green synthesis of silver nanoparticles using aqueous rinds extract of Brucea javanica (L.) Merr at ambient temperature. Mater Lett 97:181-183
Saxena A, Tripathi RM, Fahmina Z, Singh P (2012) Green synthesis of silver nanoparticles using aqueous solution of Ficus benghalensis leaf extract and characterization of their antibacterial activity. Mater Lett 67:91-94

Shahverdi AR, Fakhimi A, Shahverdi HR, Minaian S (2007) Synthesis and effect of silver nanoparticles on the antibacterial activity of different antibiotics against Staphylococcus aureus and Escherichia coli. Nanomed Nanotech Biol Med 3(2):168-171

Simakin AV, Voronov VV, Kirichenko NA, Shafeev GA (2004) Nanoparticles produced by laser ablation of solids in liquid environment. Appl Phys A 79:1127

Stamplecoskie KG, Scaiano JC (2010) Light emitting diode can control the morphology and optical properties of silver nanoparticles. J Am Chem Soc 132:1825-1827

Tran TTT, Havu TT, Nguyen TH (2013) Biosynthesis of silver nanoparticles using Tithonia diversifolia leaf extract and their antimicrobial activity. Mater Lett 105:220-223

Valentina AL, Boris FM (2013) Spectroscopy study of silver nanoparticles fabrication using synthetic humic substances and their antimicrobial activity. Spectrochim Acta Part A Mol Biomol Spectrosc 108:115-122

Valli JS, Vaseeharan B (2012) Biosynthesis of silver nanoparticles by Cissus quadrangularis extracts. Mater Lett 82:171-173

Vanaja M, Annadurai G (2012) Coleus aromaticus leaf extract mediated synthesis of silver nanoparticles and its bactericidal activity. Appl Nanosci 3:217-223

Wang T, Kaempgen M, Nopphawan P, Wee G, Mhaisalkar S, Srinivasan M (2010) Silver nanoparticle-decorated carbon nanotubes as bifunctional gas-diffusion electrodes for zinc-air batteries. J Power Sources 195:4350-4355

Wang XS, Dong Q, Zuo JP, Frong JN (2003) Structures and potential immunological activity of a pectin from Centella asiatica (L.) Urban. Carbohydr Res 338:2393-2402

Yang Y, Matsubara S, Xiong L (2007) Solvothermal synthesis of multiple shapes of silver nanoparticles and their SERS properties. J Phys Chem 111:9095-9104

Zhao GJ, Stevens SE (1998) Multiple parameters for the comprehensive evaluation of the susceptibility of Escherichia coli to the silver ion. Biometals 11:27-32 